\title{
Anaerobic digestion of piggery waste. 1 . The influence of detention time and manure concentration
}

\author{
A. F. M. van Velsen \\ Department of Water Purification, Agricultural University, Wageningen, \\ the Netherlands
}

Accepted: 20 April 1977

Key words: Anaerobic digestion, piggery waste, odour control

\section{Summary}

The influence of the manure concentration - in the range of 50 to $112.5 \mathrm{~g}$ total solids (TS)/litre - and the detention time - in the range of 40 to 10 days - upon the anaerobic digestion of piggery waste was investigated in laboratory experiments (1.5 - 6 litres) and in pilot plant experiments (240 litres). In spite of high ammonia nitrogen concentrations a stable digestion could be achieved and maintained at all manure concentrations and all detention times applied, except when $112.5 \mathrm{~g}$ TS/ litre manure was added at a 10-day detention time (space load $8.1 \mathrm{~kg}$ volatile solids (VS) per $\mathrm{m}^{3}$ per day.

Although a stable digestion could be maintained up to a space load of $5.4 \mathrm{~kg}$ VS $\mathrm{m}^{-3}$ day-1 $^{-1}$, the maximum space load at which a satisfactory reduction of objectionable manure odour was attained appeared to be about $3.6 \mathrm{~kg} \mathrm{VS} \mathrm{m}^{-3} \mathrm{day}^{-1}$.

\section{Introduction}

Intensive pig farming with its large concentrations of animals on a small space has led to a local excess of manure. The storage of the piggery waste, especially when urine and faeces are collected together, frequently causes odour nuisance, resulting in the need to treat the manure. Since conventional treatment of the excess animal waste, e.g. by means of aerobic stabilization, requires much energy, anaerobic digestion as a treatment method comes more and more into the picture.

In 1975 a research project was started in which the feasibility of piggery waste stabilization through anaerobic digestion was investigated. The primary objective of this project is to determine the reduction of objectional manure odour through anaerobic digestion. Additional goals included the determination of:

- process efficiency in recovering energy from piggery waste;

- process stability and process control, especially at changing process conditions; - the nitrogen balance in connection with the use of the digested manure as fertilizer; 
- total solids and volatile solids reduction;

- dewatering characteristics of the digested manure in relation to the raw manure. Considering the practical application of methane fermentation for piggery waste stabilization, knowledge of the maximum achievable organic loading rate is necessary for optimum process design and process performance. Since the organic loading rate can be increased by increasing the total solids concentration of the feed manure as well as by decreasing the detention time, the effect of both parameters is described in this article.

\section{Material and methods}

\section{Methods}

Analyses. Gas analyses were performed by means of gas chromatography on a Fraktovap model $\mathrm{M}$ partitioner with a dual column arrangement of molecular sieve 30/60 mesh 5A and silica gel 30/60 mesh.

Chemical oxygen demand (COD) was estimated according to Standard Methods. Supernatant COD was determined after centrifugation at $14000 \mathrm{~g}$ for 10 minutes. Ammonia nitrogen was determined by steam distillation at $\mathrm{pH} 7.4$ into boric acid indicator and titration with standard acid.

Volatile fatty acids (VFA) analyses were performed on a gas chromatograph, with a packed glass column $(1 \mathrm{~m} \times 0.4 \mathrm{~cm}$ i.d.) filled with Tween 80 on Chromosorb W-AW 80/100. Column temperature was $115^{\circ} \mathrm{C}$ and the carrier gas, $N_{2}$, was saturated with formic acid (Fohr, 1974).

Total solids concentration (TS) was determined by drying a $10 \mathrm{ml}$ sample in a $105{ }^{\circ} \mathrm{C}$ stove overnight. ${ }^{1}$ Volatile solids concentration (VS) was determined by glowing the dried samples to constant weight. ${ }^{1}$

Analysis of aromatic odorous components - phenol, p-cresol, ethylphenol, indole and skatole - was performed according to Spoelstra (1977).

Apparatus. The experiments were carried out partly on a laboratory scale (1.5 6 litres) and partly on small pilot plant scale (240 litres). Although laboratory digesters with a volume of $1.5,2,5$ and 6 litres were used, the experimental ar-

1 Since some volatile matter may be lost (Miner \& Smith, 1975) these analyses were checked by the following experiments.

- After entrapping the condensate vapours that are released during drying, the condensate was analysed to determine the ammonia nitrogen, VFA and COD concentrations. It turned out that all of the ammonia nitrogen and part of the VFA were found again in the condensate, whereas the COD value corresponded to the VFA concentration.

- To a digested manure sample containing no VFA a weighed amount of VFA, corresponding to the VFA concentration in raw manure, was added. The $\mathrm{pH}$ of the solution was comparable with the manure $\mathrm{pH}$. Both solutions, with and without VFA, were analysed in triplicate to determine the TS concentration by drying at $105^{\circ} \mathrm{C}$ overnight. The results indicated that $90 \%$ of the VFA evaporated during the analysis.

Therefore all TS and VS analyses mentioned in this article are corrected as far as VFA $(90 \%$ lost) and ammonia nitrogen (all lost) are concerned. 


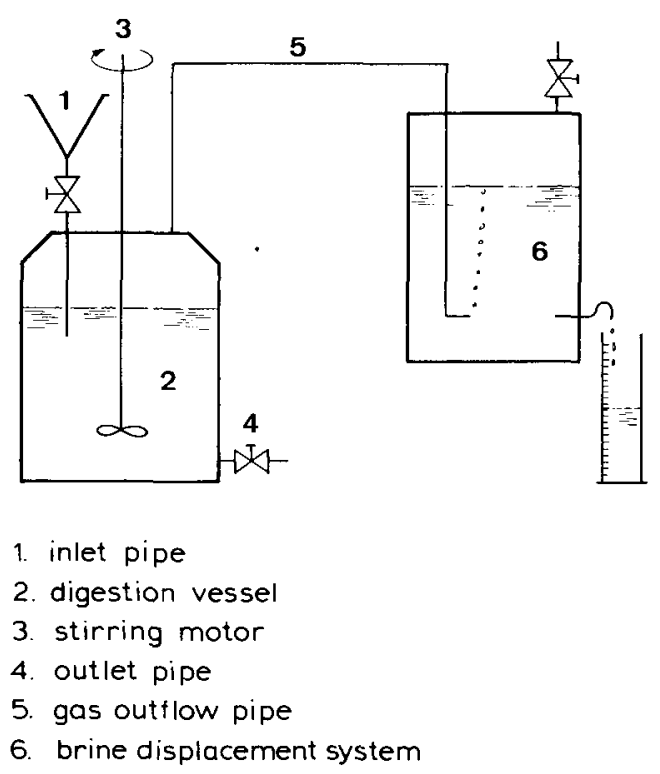

Fig. 1. Laboratory experimental digester system.

rangement was almost identical in all experiments (see Fig. 1). Gas production was determined by means of a brine displacement system (Fig. 1) using brine with a $\mathrm{pH}$ of 1 in the experiments with 1.5-litre and 2-litre digesters, and by means of a wet gas meter in the experiments with 5- and 6-litre digesters. The digestion units were placed in a temperature-controlled room of $30 \pm 2{ }^{\circ} \mathrm{C}$. Discontinuous agitation of the digester contents was accomplished by mechanical stirring for $15 \mathrm{~s}$ per 5 minutes at $100 \mathrm{rev} / \mathrm{min}$.

The pilot plant consisted of two identical isolated digestion units having a volume of 240 litres each. The digester system is shown in Fig. 2. Fluid mixing was achieved by continuous gas recirculation with a gas flow of c. 3 litres/min. Furthermore the digester contents were mixed by recirculating the digester contents with a sludge pump (capacity c. $5 \mathrm{~m}^{3} / \mathrm{h}$ ) for 15 minutes once a day. The daily feed was added during sludge recirculation. To prevent damage to the sludge pump the manure feed was sieved through a $0.5-\mathrm{cm}$ sieve to remove hairs, straw, etc.

The digester heating system consisted of a hot water tank (temperature of water $50^{\circ} \mathrm{C}$ ), a water circulation pump and stainless steel heat exchange piping inside the digester. The digester temperature $\left(32^{\circ} \mathrm{C}\right)$ was controlled by means of a thermo-couple and a thermostatic control, connected with the water circulation pump. The gas production was determined by a wet gas meter.

\section{Materials}

The piggery waste used in the experiments consisted of urine and faeces and contained no or minor amounts of bedding or litter. The manure obtained from an experimental piggery farm, was supplied at a rather constant TS concentration of 


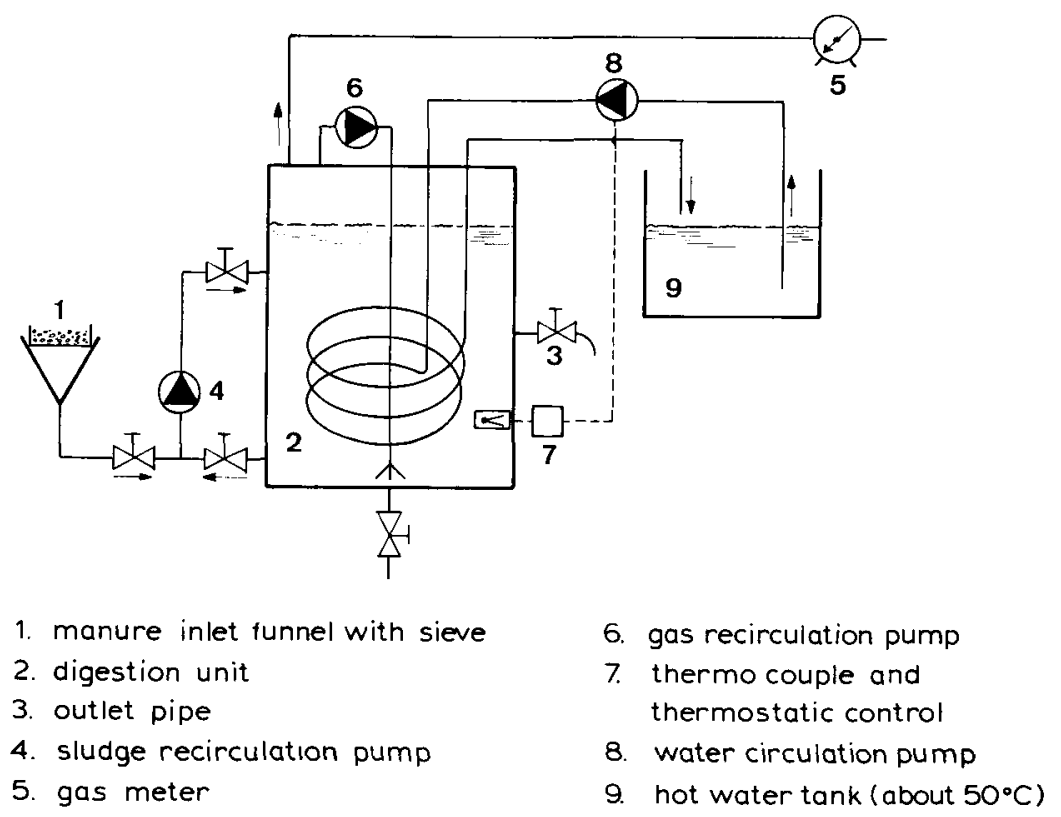

Fig. 2. Pilot plant system.

c. $130 \mathrm{~g} /$ litre and was diluted to the desired level by adding tap water. Table 1 summarizes the chemical composition of the manure after dilution to $75 \mathrm{~g}$ TS/litre. This concentration was used in most experiments except in some additional laboratory experiments where TS concentrations of 50 and $112.5 \mathrm{~g} /$ litre were applied.

The concentration of the aromatic odorous components in raw, diluted manure is shown in Table 2.

\section{Experimental procedure}

The manure concentrations and the detention times applied in the experiments are given in Table 3 . The first series of the laboratory experiments and the pilot plant experiments were seeded with digested sewage sludge, which was well adapted

Table 1. Chemical composition of piggery wast after dilution with tap water.

\begin{tabular}{|c|c|c|c|c|c|c|}
\hline & $\begin{array}{l}\text { TS } \\
(\mathrm{g} / \text { litre })\end{array}$ & $\begin{array}{l}\text { VS } \\
\mathrm{g}(/ \text { litre })\end{array}$ & $\begin{array}{l}\mathrm{NH}_{4}-\mathrm{N} \\
(\mathrm{mg} \mathrm{N} / \text { litre })\end{array}$ & $\begin{array}{l}\text { COD total } \\
\left(\mathrm{g} \mathrm{O}_{2} / \text { litre }\right)\end{array}$ & $\begin{array}{l}\mathrm{COD}_{\mathrm{s}} \\
\left(\mathrm{g} \mathrm{O}_{2} / \text { litre }\right)\end{array}$ & $\begin{array}{l}\text { VFA } \\
\text { (meq/litre) }\end{array}$ \\
\hline Minimum & 73.5 & 52.1 & 1780 & 64.5 & 17.5 & 107 \\
\hline Maximum & 77.0 & 57.7 & 2635 & 104.0 & 23.3 & 170 \\
\hline Average & 74.5 & 54.0 & 2090 & 80.3 & 19.4 & 134 \\
\hline
\end{tabular}

TS $=$ total solids; VS $=$ volatile solids; $\mathrm{COD}=$ chemical oxygen demand $\mathrm{COD}_{\mathrm{s}}=\mathrm{COD}$ of the supernatant; VFA $=$ volatile fatty acids. 
ANAEROBIC DIGESTION OF PIGGERY WASTE. 1

Table 2. Concentration of aromatic odorous components (in $\mathrm{mg} / \mathrm{litre}$ ) in $75 \mathrm{~g}$ TS /litre manure.

\begin{tabular}{lllcll}
\hline & Phenol & p-cresol & Ethylphenol & Indole & Skatole \\
& & & & & \\
Minimum & 12.6 & 118.2 & 5.7 & 0.6 & 33.4 \\
Maximum & 55.4 & 195.6 & 14.4 & 3.7 & 48.7 \\
Average & 25.2 & 149.0 & 11.2 & 2.2 & 39.6 \\
\hline
\end{tabular}

to piggery waste as it was fed with $75 \mathrm{~g}$ TS/litre piggery waste at a 40-day detention time for more than 6 months. In the second series of laboratory experiments seed sludge from the pilot plant experiment $D_{2}$ was used after a stable digestion at a 20-day detention time had been accomplished in this digester.

All digesters were fed daily except during the weekends, when only one feed was supplied, although of a double amount. The feeding procedure was as follows. After the determination of the gas production a prescribed volume (determined by the detention time) of the mixed digester contents was removed. Then the manure was added according to the organic and hydraulic load. Before and during the feeding procedure the digester contents were mixed. Because of this procedure the digesters can be considered to be completely mixed fermentors.

The analyses were carried out according to the time schedule shown in Table 4. The duration time of all experiments was at least three times the turn-over time in order to ensure a steady state and to avoid the influence of changing manure composition.

\section{Results}

The results of the laboratory experiments - together with the experimental conditions applied - are summarized in Table 5 (manure concentration $50 \mathrm{~g}$ TS/litre, Table 6 (manure concentration $75 \mathrm{~g}$ TS/litre) and Table 7 (manure concentration $112.5 \mathrm{~g}$ TS/litre). The data in these tables concern the average values of the ana-

Table 3. Manure concentration and detention time of the experiments.

\begin{tabular}{|c|c|c|c|c|}
\hline \multirow{3}{*}{$\begin{array}{l}\text { Detention time } \\
\text { (days) }\end{array}$} & \multicolumn{4}{|c|}{ Manure concentration (g TS/litre) } \\
\hline & \multirow[t]{2}{*}{50} & \multicolumn{2}{|l|}{75} & \multirow[t]{2}{*}{112.5} \\
\hline & & laboratory & pilot plant & \\
\hline 40 & & & $\mathrm{D}_{1}$ & \\
\hline 20 & & $\mathrm{~B}_{1}^{*}, \mathrm{~B}_{2}^{* *}$ & $\mathrm{D}_{2}$ & $\mathrm{C}_{1}^{* *}$ \\
\hline 16 & & $\mathrm{~B}_{3}{ }^{*}$ & & \\
\hline 15 & $\mathbf{A}_{1}{ }^{*}$ & & $\mathrm{D}_{3}$ & $\mathrm{C}_{2}{ }^{* *}$ \\
\hline 12.5 & & $\mathrm{~B}_{4}^{*}$ & & \\
\hline 12 & & & $\mathrm{D}_{4}$ & \\
\hline 10 & $\mathbf{A}_{2} *$ & $\mathrm{~B}_{5} * *$ & & $\mathrm{C}_{3}{ }^{* *}$ \\
\hline
\end{tabular}

* First series of experiments.

** Second series of experiments. 
Table 4. Analytical performance.

\begin{tabular}{|c|c|c|c|c|c|}
\hline & Daily & 3 times a week & Weekly & Fortnightly & Incidentally \\
\hline Gas production & $x$ & & & & \\
\hline Gas composition & & & $x$ & & \\
\hline $\mathrm{pH}$ & & $x$ & & & \\
\hline COD $_{\text {total }}$ & & & & & $x$ \\
\hline COD & & & & $x$ & \\
\hline VFA & & $x$ & & & \\
\hline Ammonia nitrogen & & & & $\times$ & \\
\hline Total solids & & & $x$ & & \\
\hline Volatile solids & & & $x$ & & \\
\hline Aromatic components & & & & & $x$ \\
\hline
\end{tabular}

lytical results obtained during the last 4 weeks of the experiments, when digestion processes had reached a steady state. The values of the COD reduction mentioned in Tables 5 to 8 have been calculated from the amount of COD removed via methane gas and the initial manure COD (Table 1). The methane content of the digester gas, produced in Experiments $A_{1}, A_{2}, B_{3}$ and $B_{4}$, is high in comparison

Table 5. Summary data at steady state operation of laboratory digest ers, fed with $50 \mathrm{~g} \mathrm{TS} /$ litre manure.

\begin{tabular}{|c|c|c|}
\hline & Exp. A 1 & Exp. $A_{2}$ \\
\hline Working digester volume (litres) & 1.5 & 1.5 \\
\hline Duration experiment (days) & 92 & 60 \\
\hline Detention time (days) & 15 & 10 \\
\hline Organic load: $\mathrm{kg}$ COD m $\mathrm{m}^{-3}$ day $^{-1}$ & 3.5 & 5.3 \\
\hline $\mathrm{kg} \mathrm{VS} \mathrm{m}^{-3}$ day $^{-1}$ & 2.4 & 3.6 \\
\hline Gas production (litres gas $1 \mathbf{r}^{-1} /$ day $\left.^{-1}\right)^{*}$ & 0.650 & 0.713 \\
\hline Gas composition $\left(\% \mathrm{CH}_{4}\right)$ & 84.9 & 82.8 \\
\hline COD removal (g COD/litre manure) $)^{* *}$ & 20.37 & 14.47 \\
\hline Total COD reduction $(\%)$ & 44.4 & 31.5 \\
\hline \multicolumn{3}{|l|}{ Digester effluent } \\
\hline $\mathrm{pH}$ & 7.6 & 7.45 \\
\hline $\mathrm{NH}_{4}-\mathrm{N}$ (as mg N/litre) & 1700 & 1832 \\
\hline TS $(\mathrm{g} /$ litre $)$ & 33.2 & 37.4 \\
\hline VS (g/litre) & 20.7 & 24.4 \\
\hline $\mathrm{COD}_{\mathrm{s}}$ (mg/litre) & 6200 & 10000 \\
\hline VFA (meq/litre) & 12.9 & 38.6 \\
\hline Acetic acid (meq/litre) & 4.5 & 4.1 \\
\hline Propionic acid (meq/litre) & 4.1 & 33.1 \\
\hline TS reduction $(\%)$ & 33.9 & 35.5 \\
\hline VS reduction $(\%)$ & 42.2 & 31.8 \\
\hline $\mathrm{COD}_{\mathrm{s}}$ reduction $(\%)$ & 63.1 & 40.0 \\
\hline VFA reduction $(\%)$ & 88.6 & 61.6 \\
\hline
\end{tabular}

* Gas production in litres of gas per litre working digester volume $\left(l_{\mathrm{r}}\right)$.

** Calculated from gas production and gas composition. 
Table 6. Summary data at steady state operation of laboratory experiments, fed with $75 \mathrm{~g}$ TS/litre manure.

\begin{tabular}{|c|c|c|c|c|c|}
\hline & Exp. $\mathbf{B}_{1}$ & Exp. $B_{2}$ & Exp. $\mathbf{B}_{3}$ & Exp. $\mathbf{B}_{4}$ & Exp. $B_{5}$ \\
\hline Working digester volume (litres) & 6 & 5 & 2 & 2 & 6 \\
\hline Duration experiments (days) & 102 & 109 & 92 & 94 & 93 \\
\hline Detention time (days) & 20 & 20 & 16 & 12.5 & 10 \\
\hline Organic load: $\mathrm{kg} \mathrm{COD} \mathrm{m}^{-3} \mathrm{day}^{-1}$ & 4.0 & 4.0 & 5.0 & 6.4 & 8.0 \\
\hline $\mathrm{kg} \mathrm{VS} \mathrm{m} \mathrm{m}^{-3}$ day $^{-1}$ & 2.7 & 2.7 & 3.4 & 4.3 & 5.4 \\
\hline Gas production (litres gas $l_{r}^{-1}$ dayl)* & 0.897 & 0.810 & 0.930 & 1.032 & 1.300 \\
\hline Gas composition $\left(\% \mathrm{CH}_{4}\right)$ & 73.8 & 75.6 & 83.4 & 83.0 & 77.1 \\
\hline $\mathrm{COD}$ removal (g COD/litre manure) $* *$ & 32.57 & 30.13 & 30.53 & 26.34 & 24.66 \\
\hline Total COD reduction $(\%)$ & 44.6 & 41.7 & 41.7 & 36.4 & 34.2 \\
\hline \multicolumn{6}{|l|}{ Digester effluent } \\
\hline $\mathrm{pH}$ & 7.7 & 7.8 & 7.9 & 7.8 & 7.7 \\
\hline $\mathrm{NH}_{4}-\mathrm{N}$ (as mg $\mathrm{N} /$ litre) & 2510 & 2740 & 2615 & 2580 & 2635 \\
\hline TS (g/litre) & 52.3 & 50.9 & 53.1 & 55.5 & 58.0 \\
\hline VS (g/litre) & 34.1 & 30.0 & 34.9 & 35.1 & 37.0 \\
\hline $\mathrm{COD}_{\mathrm{s}}(\mathrm{mg} /$ litre $)$ & 6750 & 5700 & 8500 & 9150 & 8600 \\
\hline VFA (meq/litre) & 3.1 & 5.5 & 10.7 & 17.6 & 23.4 \\
\hline Acetic acid (meq/litre) & 2.9 & 5.5 & 5.3 & 10.0 & 11.0 \\
\hline Propionic acid (meq/litre) & 0 & 0 & 5.2 & 7.3 & 11.5 \\
\hline TS reduction $(\%)$ & 28.0 & 32.1 & 29.5 & 26.3 & 25.8 \\
\hline VS reduction $(\%)$ & 37.4 & 44.4 & 34.4 & 34.0 & 31.5 \\
\hline $\mathrm{COD}_{\mathrm{s}}$ reduction $(\%)$ & 75.0 & 75.5 & 66.0 & 63.4 & 63.0 \\
\hline VFA reduction $(\%)$ & 97.7 & 95.9 & 92.0 & 86.9 & 82.6 \\
\hline
\end{tabular}

* and ${ }^{* *}$ See notes to Table 5 .

with the gas produced in the other experiments. This difference has to be attributed to the use of a brine displacement system to collect the digester gas in the former experiments. In all laboratory digesters mixing was necessary to prevent the formation of a floating layer. Nevertheless, in some digesters a tough floating layer was formed, which could be disrupted by continuous stirring for 10 minutes. Scum formation appeared to occur only if the digestion process was not in balance. In none of the experimental units retarded digestion has been observed except in Experiment $\mathrm{C}_{3}$, where the feed consisted of concentrated manure (112.5 g TS/litre) and a detention time of 10 days was applied.

The conditions and results of the pilot plant experiments are summarized in Table 8. One digester was run at various detention times, viz 20,15 and 12 days, whereas the other unit acting as a reference digester was run at a 40-day detention time.

In both digesters continuous gas recirculation was applied. In this way a uniform digester temperature could be achieved whereas the formation of a floating layer could be prevented. No scum formation was observed except during start-up periods and after digestion disturbance. Due to a failure in the temperature control system during experiment $\mathrm{D}_{2}$, the digester temperature was $50{ }^{\circ} \mathrm{C}$ for a period of 
c. 24 hours. This resulted in a severe unbalance of the digestion process as was indicated by the sudden decrease of gas production, the low methane content of the digester gas and the strong increase of the VFA concentration.

To accomplish process recovery no feed was supplied for 3 days, followed by a period in which the quantity of the feed was increased in steps: for a period of 2 days 6 litres of manure, then for a period of 3 days 9 litres of manure, and subsequently with a daily quantity of 12 litres according to the original detention time of 20 days. The course of the process recovery is shown in Fig. 3. Although gas production and gas composition soon reached the original level the VFA concentration increased strongly, especially that of propionic acid. However, after 5 weeks the propionic acid concentration decreased rapidly, which indicated that the recovery of the digestion process had been completed.

As the objectionable manure odour has to be attributed to the presence of aromatic components, such as phenol, p-cresol, ethylphenol, indole and skatole, as well as VFA (Schaefer et al., 1974), the concentration of these components has been determined in raw manure as well as in the digested manure at the end of some experiments. The results of these analyses are shown in Fig. 4 . When smelling the digester effluents it appeared that digested manure from the pilot plant experi-

Table 7. Summary data at steady state operation of laboratory experiments, fed with $112.5 \mathrm{~g}$ TS/litre manure.

\begin{tabular}{|c|c|c|c|}
\hline & Exp. $C_{1}$ & Exp. $C_{2}$ & Exp. $C_{3}$ \\
\hline Working digester volume (litres) & 5 & 5 & 5 \\
\hline Duration experiment (days) & 109 & 109 & 109 \\
\hline Detention time (days) & 20 & 15 & 10 \\
\hline Organic load: $\mathrm{kg}$ COD m $\mathrm{m}^{-3} \mathrm{day}^{-1}$ & 6.0 & 8.0 & 12.0 \\
\hline $\mathrm{kg} \mathrm{VS} \mathrm{m} \mathrm{m}^{-3} \mathrm{day}^{-1}$ & 4.1 & 5.4 & 8.1 \\
\hline Gas production (litres gas $1_{\mathrm{r}}^{-1}$ day $\left.{ }^{-1}\right)^{*}$ & 1.120 & 1.448 & 0.534 \\
\hline Gas composition $\left(\% \mathrm{CH}_{4}\right)$ & 74.7 & 74.4 & 67.6 \\
\hline COD removal (g COD/litre manure)** & 41.16 & 39.75 & 8.88 \\
\hline Total COD reduction $(\%)$ & 31.7 & 30.5 & 6.8 \\
\hline \multicolumn{4}{|l|}{ Digester effluent } \\
\hline pH & 7.9 & 7.9 & 7.55 \\
\hline $\mathrm{NH}_{4}-\mathrm{N}$ (as $\mathrm{mg} \mathrm{N} /$ litre) & 3950 & 3910 & 3975 \\
\hline TS (g/litre) & 83.1 & 85.3 & 104.5 \\
\hline VS (g/litre) & 50.7 & 52.7 & 71.1 \\
\hline $\mathrm{COD}_{\mathrm{s}}(\mathrm{mg} /$ litre $)$ & 12000 & 13000 & 30600 \\
\hline VFA (meq/litre) & 18.9 & 20.1 & 201.3 \\
\hline Acetic acid (meq/litre) & 18.1 & 18.0 & 111.0 \\
\hline Propionic acid /meq/litre) & 0.8 & 1.7 & 63.5 \\
\hline TS reduction $(\%)$ & 27.1 & 25.2 & 8.3 \\
\hline VS reduction $(\%)$ & 36.9 & 34.4 & 11.5 \\
\hline $\mathrm{COD}_{\mathrm{s}}$ reduction $(\%)$ & 66.4 & 63.6 & 14.3 \\
\hline VFA reduction $(\%)$ & 90.6 & 90.0 & 0.2 \\
\hline
\end{tabular}

* and ** See notes to Table 5 . 
Table 8. Summary data at steady state operation of pilot plant experiments, fed with $75 \mathrm{~g}$ TS/litre manure.

\begin{tabular}{|c|c|c|c|c|}
\hline & Exp. $D_{1}$ & Exp. $\mathrm{D}_{2}$ & Exp. $D_{3}$ & Exp. $D_{4}$ \\
\hline Working digester volume (litres) & 240 & 240 & 240 & 240 \\
\hline Duration experiment (days) & 200 & 100 & 92 & 40 \\
\hline Detention time (days) & 40 & 20 & 15 & 12 \\
\hline Organic load: $\mathrm{kg} \mathrm{COD} \mathrm{m}^{-3}$ day $^{-1}$ & 2.0 & 4.0 & 5.3 & 6.7 \\
\hline $\mathrm{kg} \mathrm{VS} \mathrm{m}^{-3} \mathrm{day}^{-1}$ & 1.4 & 2.7 & 3.6 & 4.5 \\
\hline Gas production (litres gas $\mathrm{l}_{\mathrm{r}}^{-1}$ day $\left.^{-1}\right)^{*}$ & 0.420 & 0.850 & 1.030 & 1.180 \\
\hline Gas composition $\left(\% \mathrm{CH}_{4}\right)$ & 73.9 & 75.2 & 76.4 & 76.3 \\
\hline COD removal (g COD/litre manure)** & 30.54 & 31.45 & 29.04 & 26.58 \\
\hline Total COD reduction $(\%)$ & 49.0 & 44.3 & 43.9 & 40.3 \\
\hline \multicolumn{5}{|l|}{ Digester effluent } \\
\hline $\mathrm{pH}$ & - & - & - & - \\
\hline $\mathrm{NH}_{4}-\mathrm{N}$ (as mg N/litre) & 2965 & 2820 & 2675 & 2315 \\
\hline TS (g/litre) & 49.2 & 45.0 & 49.0 & 51.7 \\
\hline VS (g/litre) & 28.8 & 27.6 & 31.3 & 31.8 \\
\hline $\mathrm{COD}_{\mathrm{s}}$ (mg/litre) & 6600 & 6350 & 6550 & 6100 \\
\hline VFA (meq/litre) & 4.2 & 4.2 & 3.5 & 4.7 \\
\hline Acetic acid (meq/litre) & 4.2 & 4.0 & 3.5 & 3.9 \\
\hline Propionic acid (meq/litre) & 0 & 0.2 & 0 & 0.8 \\
\hline TS reduction (\%) & 34.4 & 40.0 & 30.8 & 31.1 \\
\hline VS reduction $(\%)$ & 44.1 & 48.9 & 39.2 & 38.3 \\
\hline $\mathrm{COD}_{\mathrm{s}}$ reduction $(\%)$ & 61.2 & 74.1 & 62.9 & 65.5 \\
\hline VFA reduction $(\%)$ & 96.9 & 96.9 & 97.4 & 96.5 \\
\hline
\end{tabular}

* and ${ }^{* *}$ See notes to Table 5 .

ments did not have any of the original objectionable odours. However, digested manure from the laboratory units was less satisfactory in this respect.

\section{Discussion}

Piggery waste, consisting mainly of carbohydrates, lipids and proteins, turned out to be a good substrate for anaerobic digestion. Successful digestion could be obtained at space loads from 1.4 to $5.4 \mathrm{~kg} \mathrm{VS} \mathrm{m}^{-3}$ day-1$^{-1}$. A space load of $8.1 \mathrm{~kg}$ VS $\mathrm{m}^{-3}$ day $^{-1}$ as applied in experiment $\mathrm{C}_{3}$, however, resulted in a severe accumulation of VFA and therefore in retarded methane production. The values of the obtained organic load are in accordance with results reported by Loehr (1969), indicating that animal wastes could be successfully digested at loading rates in the range of 1.6 to $6.4 \mathrm{~kg} \mathrm{VS} \mathrm{m}^{-3} \mathrm{day}^{-1}$.

\section{Process efficiency}

The COD reduction obtained in the pilot plants experiments varied from $40.3 \%$ at a 12-day detention time to $49 \%$ at a 40 -day detention time, which is consider- 
ably lower than the $54.6 \%$ reported by Gramms et al. (1971). This also holds for the reduction of volatile solids. In our pilot plant experiments a VS reduction of 38.3 to $48.9 \%$ was observed, whereas Gramms et al. (1971) reported a reduction value of $60.9 \%$. These differences may be attributed to the fact that the process conditions in the experiments of Gramms et al., such as the ammonia nitrogen concentration (190 - $570 \mathrm{mg} \mathrm{N} /$ litre) and the $\mathrm{pH}(6.76-7.27)$, differed from the conditions in our experiments.

In the laboratory experiments the VS reduction varied from 31.5 to $44.4 \%$ at a balanced digestion. Furthermore, the results shown in Tables 5 to 8 indicate that the TS and VS reductions tend to decrease at decreasing detention times. However, due to sampling difficulties and possible erratic analytical methods (see analyses) the VS reduction is only a coarse parameter for describing animal waste digestion efficiency.

In stable digestion the gas production varied from 160 to 225 litres of gas per $\mathrm{kg}$ TS added, whereas the methane content of the digester gas was about $75 \%$ when gas production was measured by means of a wet gas meter. The methane production as related to the total solids fed to the digesters has been plotted versus the detention time in Fig. 5. For comparison the methane production in Fig. 5 has

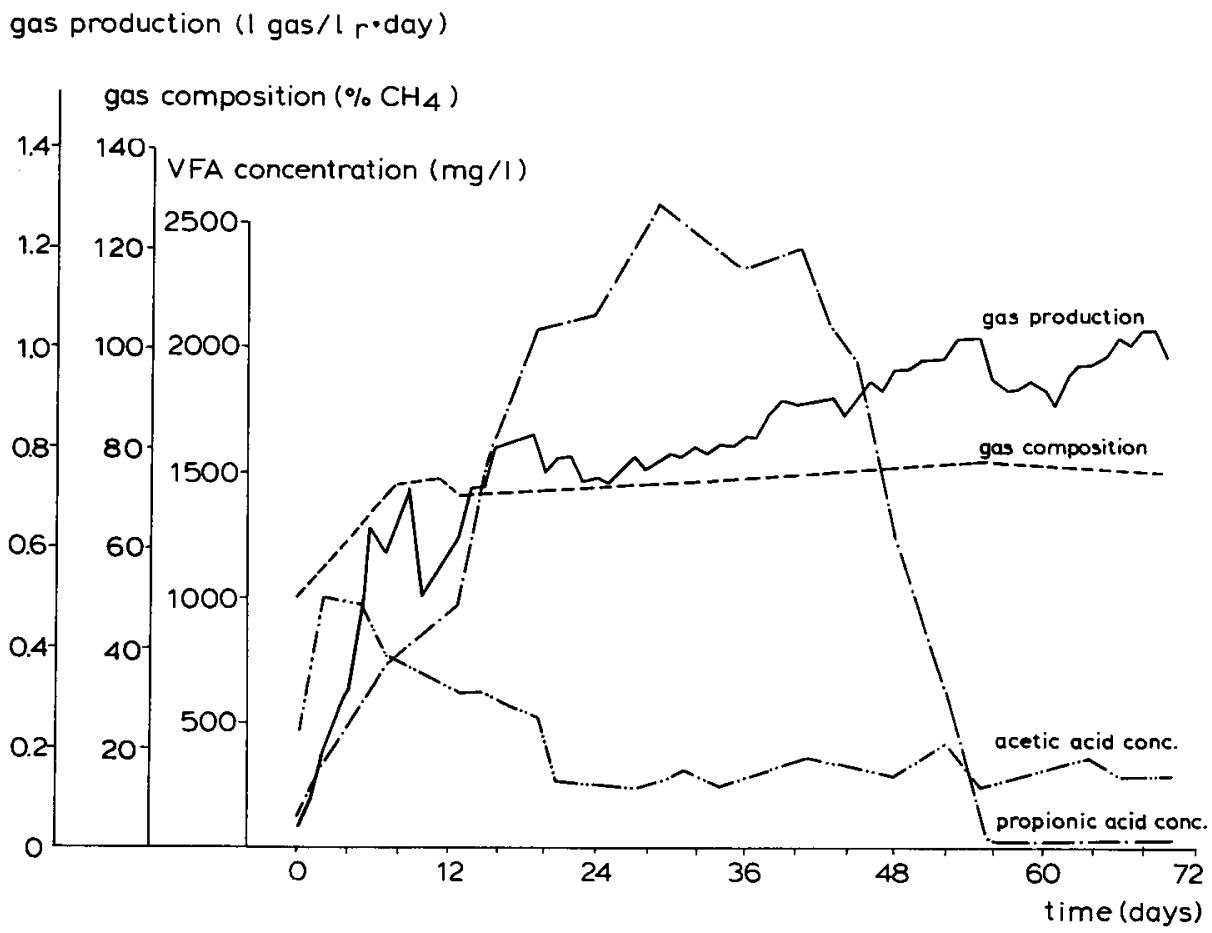

Fig. 3. Course of some process parameters after process disturbance due to a rise in temperature to $50^{\circ} \mathrm{C}$. For feeding rate see text. 
relative concentration $(\%)$

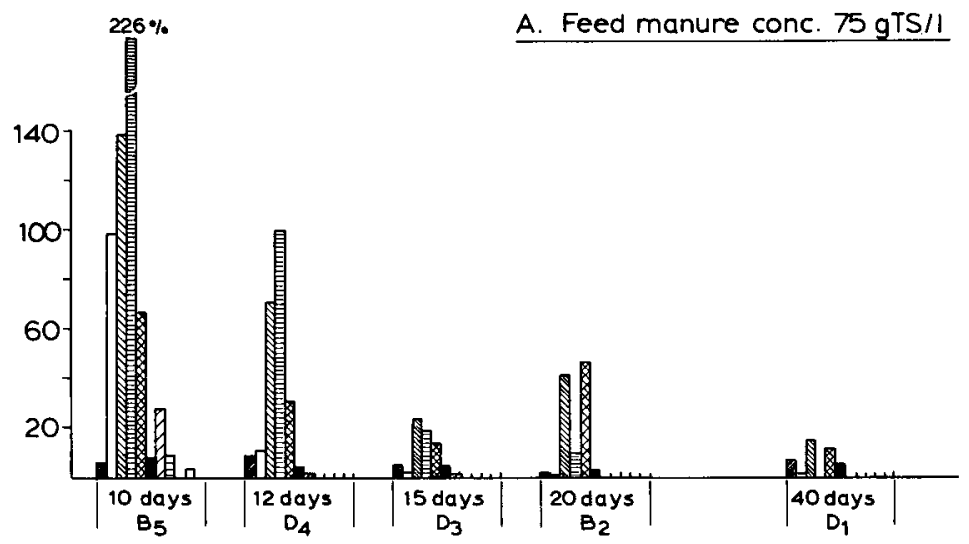

relative concentration $(\%)$

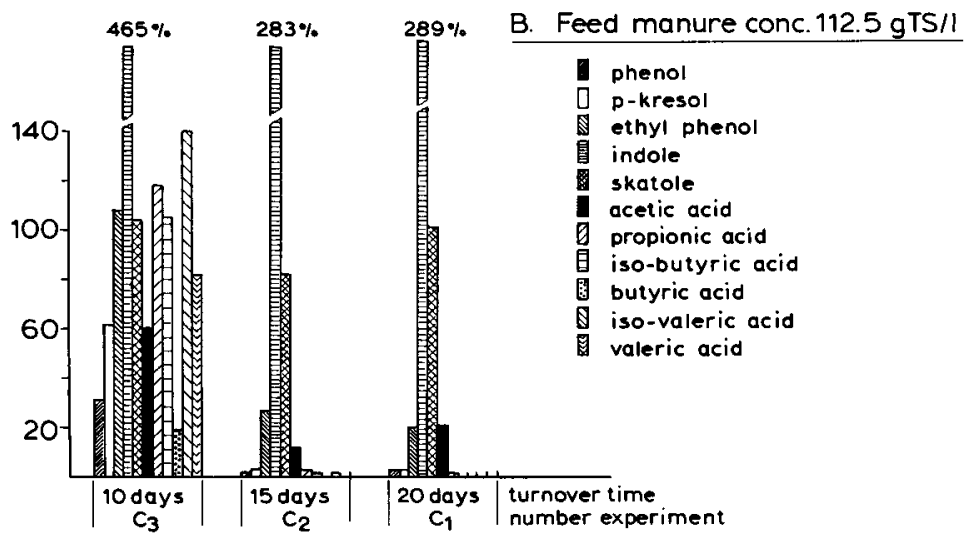

Fig. 4. Concentration of odorous components present in digested piggery waste. The concentration has been expressed in relation to the concentration in raw manure (see Table 2).

been expressed in terms of litres of methane produced per $\mathrm{kg}$ TS added. From Fig. 5 it appears that, at detention times longer than 15 days there is only a slight increase of the methane production (and consequently of the degree of stabilization of the manure) when manure concentrations of 75 and $112.5 \mathrm{~g}$ TS/litre are applied. As can be seen from Fig. 5, methane production decreases sharply at detention times shorter than 15 days in the experiments with 50 and $112.5 \mathrm{~g}$ TS/litre manure. A far less sharp decrease in methane production was observed in the experiments with $75 \mathrm{~g}$ TS/litre manure. Apparently a better process condition for a balanced digestion is obtained at a TS concentration of approximately $75 \mathrm{~g}$ TS/litre.

The effect, upon methane production, of the increase of organic load, either by increasing the TS concentration of the manure feed or by decreasing the detention time, is shown in Fig. 6. From Fig. 6 it appears that there is only a slight decrease 
of methane production when the total solids concentration of the feed is increased at a 15-day detention time. This slight decrease in methane production, however, may also be attributed to the increased organic load. On the other hand Fig. 6 clearly shows that methane production is strongly affected by detention times in the range of 15 to 10 days.

The methane production was 400 - 600 litres of methane per $\mathrm{kg}$ VS removed, the average value being 540. This corresponds to a COD of $1.33 \mathrm{~kg} \mathrm{COD} / \mathrm{kg} \mathrm{VS}$ removed. Apparently mainly volatile matter of a COD/VS ratio higher than 1 , such as lipids, fatty acids and proteins, is converted.

\section{Ammonia nitrogen concentration $\left(\mathrm{NH}_{4}-\mathrm{N}\right)$}

An increase in the TS concentration of the feed implies an increase in the $\mathrm{NH}_{4}-\mathrm{N}$ concentration in the digester fluid. Although $\mathrm{NH}_{4}-\mathrm{N}$ concentrations over $3000 \mathrm{mg} /$ litre were thought to be toxic for methane fermentation (McCarthy, 1964; Schmid \& Ripper, 1969; Patel \& Patel, 1971), especially in combination with a high pH level, the results of our experiments show that a balanced methane fermentation

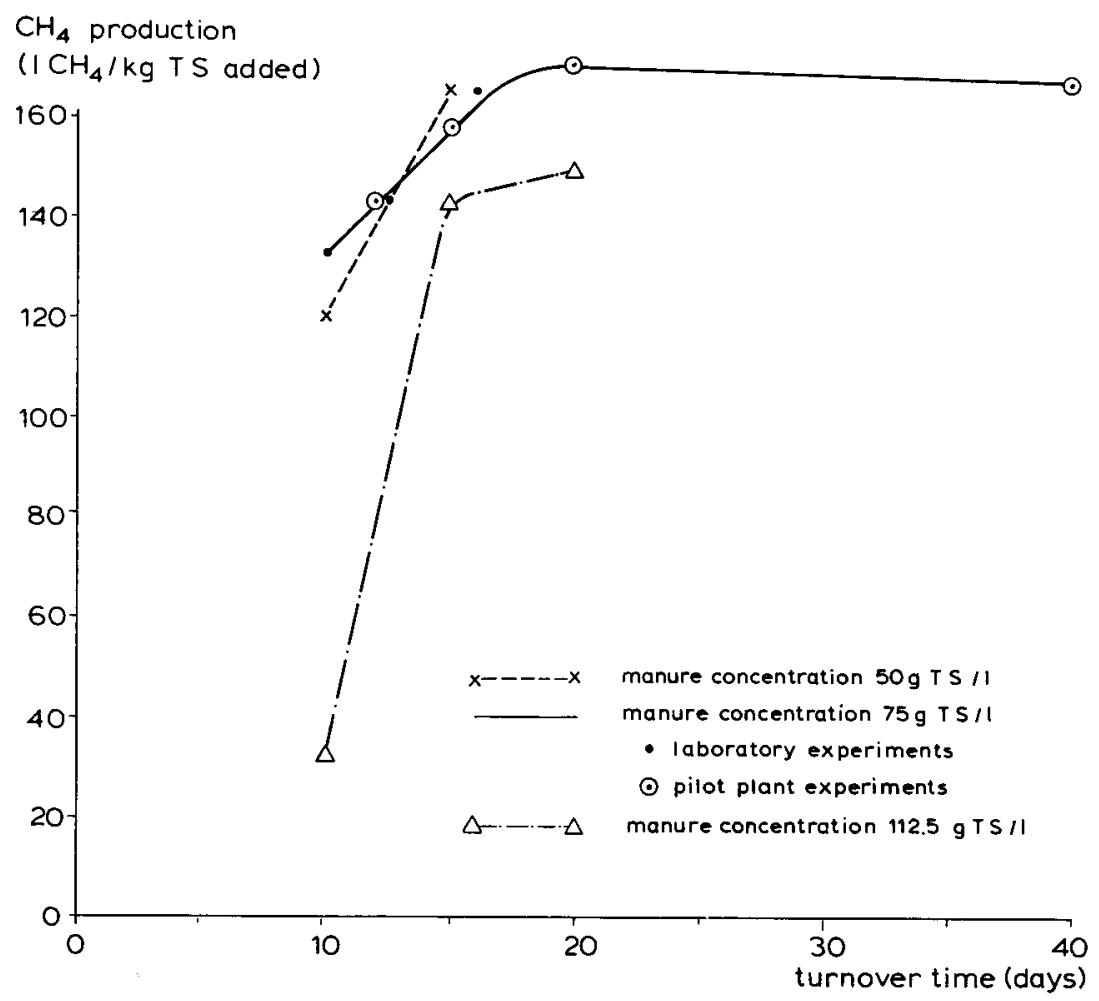

Fig. 5. Methane produktion vs. detection time at different manure feed concentrations. 


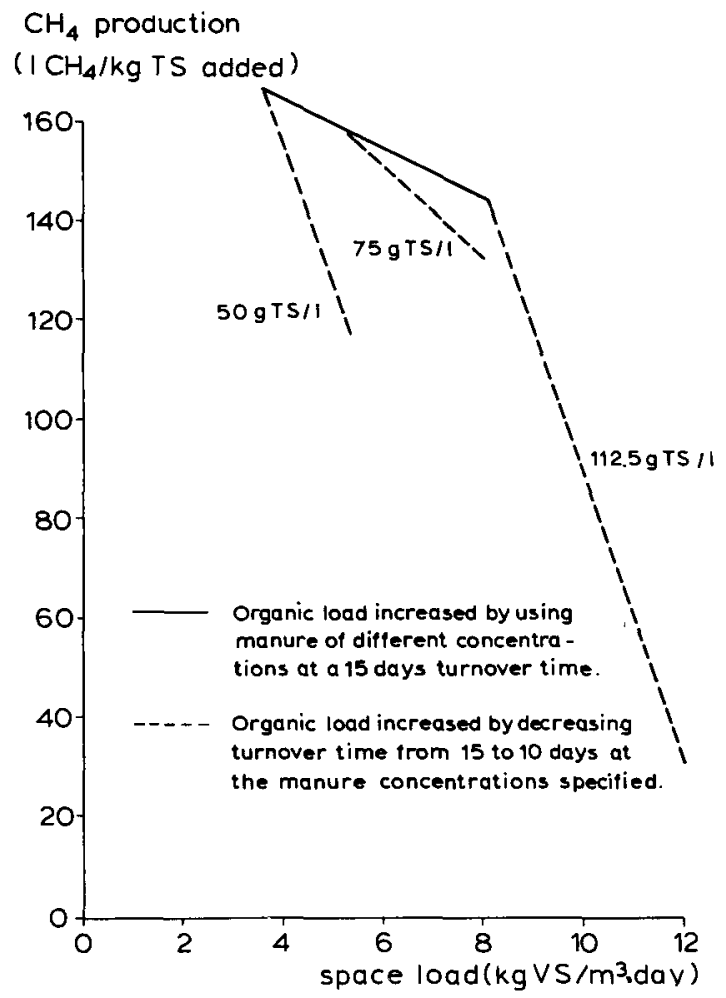

Fig. 6. Influence of the increase of organic load upon methane production.

takes place even at an $\mathrm{NH}_{4}-\mathrm{N}$ concentration of $4000 \mathrm{mg} /$ litre and a $\mathrm{pH}$ of 7.9 (Table 7). Perhaps even more interesting is the fact that the methane production rate is hardly affected by the $\mathrm{NH}_{4}-\mathrm{N}$ concentration in the range of 1650 to 4000 $\mathrm{mg} /$ litre. At a 15-day detention time we observed a linear decrease in the methane production from 166 litres $\mathrm{CH}_{4} / \mathrm{kg}$ TS added at an $\mathrm{NH}_{4}-\mathrm{N}$ concentration of 1650 $\mathrm{mg} / \mathrm{litre}$ to 144 litres $\mathrm{CH}_{4} / \mathrm{kg}$ TS added at an $\mathrm{NH}_{4}-\mathrm{N}$ concentration of $4000 \mathrm{mg}$ / litre. Interpreting these results one has to consider that, at a constant detention time, an increase in the $\mathrm{NH}_{4}-\mathrm{N}$ concentration is accompanied with an increase in the organic space load because of the more concentrated feed which has to be used. However, the influence of a high $\mathrm{NH}_{4}-\mathrm{N}$ concentration upon the metabolism rate of the methanogenic bacteria does not become clear from these results, since nethane formation is not the process rate-limiting step in these experiments, as will be discussed below. Successful digestion of piggery waste at $\mathrm{NH}_{4}-\mathrm{N}$ concentrations as high as $3450 \mathrm{mg} /$ litre has also been described by Kroeker et al. (1975). Melbinger \& Donnellon (1971) reported that $\mathrm{NH}_{4}-\mathrm{N}$ concentrations of $2700 \mathrm{mg}$ / litre have existed in acclimated high rate digesters without affecting the gas production or the volatile matter destruction. According to Melbinger \& Donnellon $\mathrm{NH}_{4}-\mathrm{N}$ does not become toxic or inhibitive at concentrations over $1700-1800 \mathrm{mg} /$ 
litre, unless the rate of its formation increases more rapidly than the acclimation of methanogenic organisms. From the available data the impression is gathered that a bacterial population can adapt itself to a high $\mathrm{NH}_{4}-\mathrm{N}$ concentration.

\section{Reduction of odorous components}

The main odorous components present in piggery manure - VFA, phenol, p-cresol, ethylphenol, indole and skatole (Schaefer et al., 1974) - are formed through anaerobic microbiological activity. It is peculiar that these components also disappear under anaerobic conditions, as can be seen from Fig. 4.

The results of our experiments (Fig. 4) indicate that (1) elimination increases at increasing detention times; (2) the VFA are eliminated faster than the aromatic components; (3) a better elimination, especially of indole and skatole, is obtained at a low TS concentration in the digester fluid.

In the experiments with $50 \mathrm{~g}$ TS/litre manure a decrease of the detention time from 15 to 10 days resulted in an increase in the VFA concentration, especially that of the propionic acid concentration (Table 5). The concentrations of phenol, p-cresol, ethylphenol, indole and skatole were not determined in these experiments.

When, in the pilot plant experiments, manure with $75 \mathrm{~g}$ TS/litre was used, the VFA concentration was 3.5 to $4.2 \mathrm{meq} /$ litre at all detention times examined, viz $40,20,15$ and 12 days (Table 8), whereas in the laboratory experiments the VFA concentration increased from $3.1 \mathrm{meq} /$ litre at a 20 -day detention time to 23.4 meq/litre at a 10-day detention time (Table 6). In these experiments, too, the increase of the VFA concentration was caused mainly by an increase in the propionic acid concentration. Of the aromatic components, phenol is almost completely eliminated within 10 days (see Fig. 4), whereas the reduction of p-cresol increased from $2 \%$ at a 10 -day detention time to $89 \%$ at a 12-day detention time. An explanation for the remarkably better elimination rate at a 12-day detention time may be (1) the organisms responsible for the elimination of p-cresol have - under these conditions - a generation time between 10 and 12 days, or (2) at a 12-day detention time all easily degradable constituents of the manure feed have been reduced to a low concentration, which gives micro-organisms the opportunity of metabolizing less degradable substrates, such as some aromatic components. In the experiments with a 10-day detention time the indole concentration became as high as $266 \%$ in comparison with the indole concentration in the raw manure, which indicates that its formation rate surpasses the elimination rate. When, however, the detention time is increased the indole elimination rate becomes higher than the formation rate and at a 40-day detention time indole has disappeared completely.

When the results of Experiments $D_{3}$ and $D_{1}$ are compared with the results of Experiment $\mathbf{B}_{2}$ (see Fig. 4) it again appears that in laboratory scale experiments the reduction of odorous components is lower than in the pilot plant experiments. Accordingly the quality of the pilot plant effluents was much higher than the quality of the laboratory digester effluents with respect to objectionable odour.

In the experiments with $112.5 \mathrm{~g}$ TS/litre manure the VFA concentration was c. $18 \mathrm{meq} /$ litre at a detention time of both 20 and 15 days (Table 5). At a 10-day 
detention time no VFA reduction occurred at all. The propionic acid concentration in the digestion liquid was even higher than in the manure feed. In spite of a very high VFA concentration of $200 \mathrm{meq} /$ litre in this experiment the digester $\mathrm{pH}$ remained 7.55 due to the high buffer capacity of the solution. In all experiments with $112.5 \mathrm{~g}$ TS/litre manure no elimination of indole and skatole occurred, not even at a 20-day detention time. This poor result may be due to the fact that high space loads were applied, which leads to an acceptable elimination of only the easily degradable organic matter.

\section{Process balance}

As volatile fatty acids can be considered to be intermediates in the conversion of complex organic matter into methane and carbon dioxyde, the VFA concentration is a useful indicator of process balance (Kroeker et al., 1975; McCarthy, 1964). The VFA concentration in the pilot plant experiments - in these experiments almost exclusively consisting of acetic acid - was $3.5-4.2 \mathrm{meq} / \mathrm{litre}$. In our laboratory experiments the VFA concentrations in stable digestion units were in the range of 3.1 to $38.6 \mathrm{meq} / \mathrm{litre}$. At a 20-day detention time acetic acid was the only volatile fatty acid present, whereas at decreasing detention times the increase of the VFA concentration was mainly caused by an increase in the propionic acid concentration. With respect to the recovery of the digestion process after the process disturbance mentioned above (see Fig. 3) we found that much more time was involved in the recovery of the propionic acid degradation than in that of other VFA. Hobson et al (1974) also observed that at failing digestion propionic acid was the principal VFA. From all these observations it appears that propionic acid is a critical factor in anaerobic digestion of piggery waste and that the course of the propionic acid concentration is a more useful indicator of process balance than the total VFA concentration.

\section{Process rate-limiting step}

From the point of view of process optimalization it is important to get a clear insight into the separate biochemical steps of the digestion process, viz hydrolysis, acid formation and methane formation. For this purpose it is assumed that (1) in hydrolysis undissolved organic matter ${ }^{1}$ is converted into dissolved fragments; (2) VFA, hydrogen and carbon dioxyde are exclusively formed by acid-forming bacteria; (3) all methane produced originates from the end-products of acid formation. The degree of hydrolysis, acid formation and methane formation can now be calculated by the following equations:

Hydrolysis $(\%)=100(\mathrm{G}+\mathrm{S}) / \mathrm{M}$.

Acid formation $(\%)=100(\mathrm{G}+\mathrm{V}) / \mathrm{M}$.

Methane formation $(\%)=100 \mathrm{G} / \mathrm{M}$.

1 Arbitrarily defined as the material that is precipitated during centrifugation at $14000 \mathrm{~g}$ for 10 minutes. 

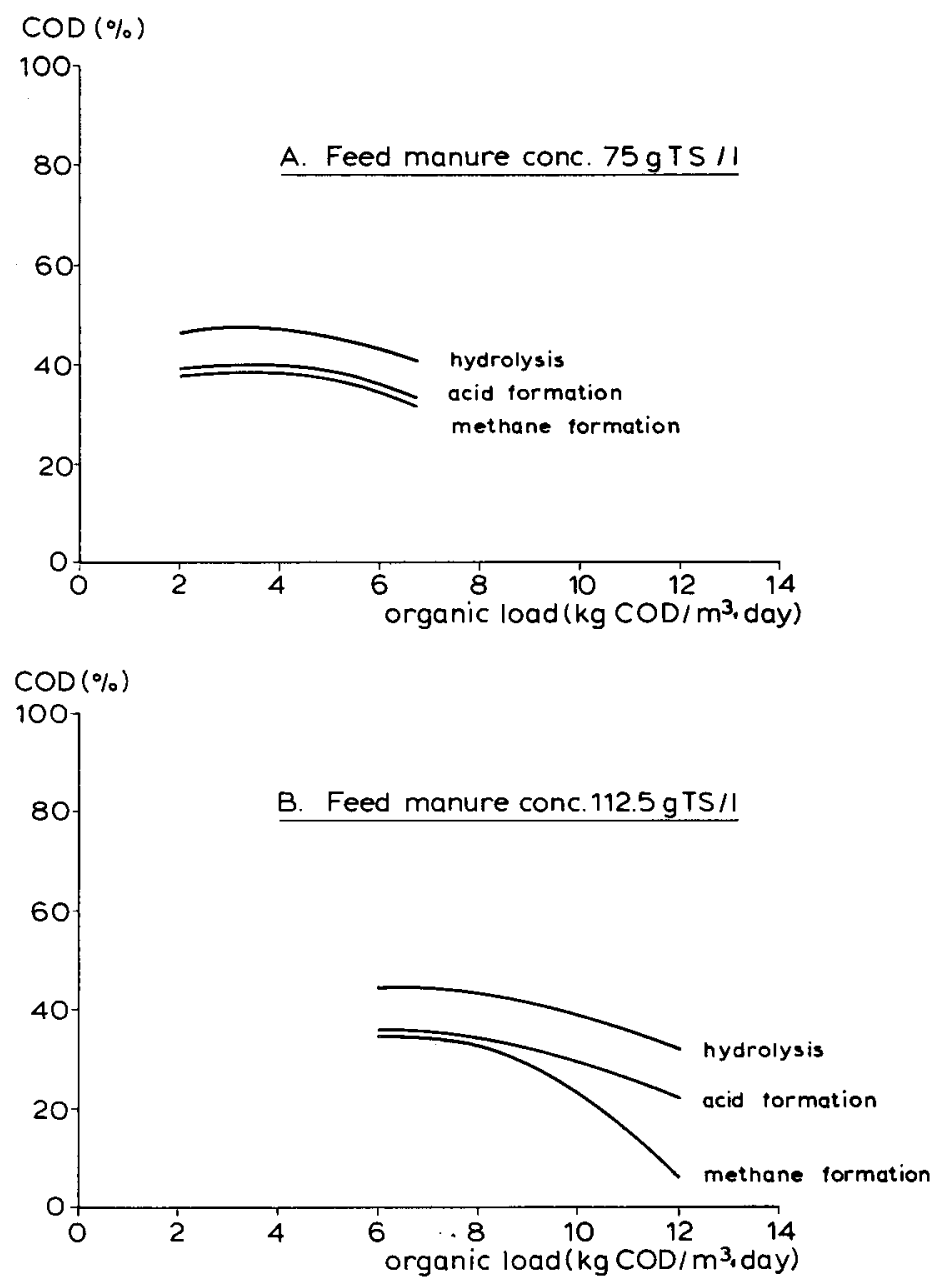

Fig. 7. Influence of the organic load upon hydrolysis, acid formation and methane formation.

in which: $\mathrm{G}=\mathrm{COD}$ removed via methane gas $\left(\mathrm{g} \mathrm{O}_{2} /\right.$ litre manure $)$

$\mathrm{S}=\mathrm{COD}$ supernatant $\left(\mathrm{g} \mathrm{O} \mathrm{O}_{2} /\right.$ litre)

$\mathrm{M}=$ total manure $\mathrm{COD}$ ( $\mathrm{g} \mathrm{O}_{2} /$ litre manure)

$\mathrm{V}=\mathrm{COD}$, corresponding with the VFA concentration in the digester effluent $\left(\mathrm{g} \mathrm{O}_{2}\right.$ /litre).

The results of these calculations have been plotted versus the organic load in Fig. 7a (pilot plant experiments) and Fig. 7b (laboratory experiments, using a manure concentration of $112.5 \mathrm{~g}$ TS/litre). The results of the pilot plant experiments indicate that at a decrease of the detention time in the range of 40 to 12 days the rate of the biochemical steps decrease to the same extent. These results lead 
to the conclusion that the first step in the anaerobic conversion - viz hydrolysis is the rate-limiting step in the overall process. Hobson et al. (1974) and Maki (1954) have already suggested that hydrolysis is the rate-limiting factor when organic matter is digested. According to Maki the cellulose hydrolysis in particular could be one of the rate-limiting steps in anaerobic digestion. In the experiments with $112.5 \mathrm{~g}$ TS/litre manure (Fig. 7b) hydrolysis is again the rate-limiting step when the detention time is decreased from 20 to 15 days. When the detention time is decreased from 15 days (space load $5.4 \mathrm{~kg} \mathrm{VS} \mathrm{m}^{-3}$ day-1) to 10 days (space load $8.1 \mathrm{~kg} \mathrm{VS} \mathrm{m}^{-3}$ day $^{-1}$ ) the methane formation rate decreases far stronger than the hydrolysis and acid formation rates. This indicates that methane formation is the rate-limiting step. Acid formation was never found to be the rate-limiting step in the anaerobic fermentation of piggery waste.

\section{Practical application}

Considering the practical application of anaerobic fermentation for the stabilization of piggery waste, the most important requirements are (1) a satisfactory reduction of odorous components, and (2) optimum process economics. Optimum process economics are obtained when a high space load is combined with a maximum gas production. From the results presented in this article it appears that a balanced digestion can be performed at a space load of c. $5.4 \mathrm{~kg} \mathrm{VS} \mathrm{m}^{-3} \mathrm{day}^{-1}$, either by digesting $112.5 \mathrm{~g}$ TS/litre manure at a 15 -day detention time resulting in a methane production of 144 litres $\mathrm{CH}_{4} / \mathrm{kg}$ TS added or by digesting $75 \mathrm{~g}$ TS/litre manure at a 10-day detention time resulting in a methane production of 133 litres $\mathrm{CH}_{4} / \mathrm{kg}$ TS added. However, at a space load of $5.4 \mathrm{~kg} \mathrm{VS} \mathrm{m}^{-3}$ day $^{-1}$ the reduction of odorous components is less satisfactory. In order to create a situation in which both requirements are met, the optimum space load must be c. $3.6 \mathrm{~kg} \mathrm{VS} \mathrm{m}^{-3}$ day $^{-1}$, provided that this load is obtained by digesting $75 \mathrm{~g}$ TS/litre manure at a 15-day detention time. This will result in a methane production of 157 litres $\mathrm{CH}_{4} \mathrm{~kg}$ TS added (see Table 6).

\section{Conclusions}

1. Piggery waste, consisting of combined urine and faeces, is amenable to anaerobic digestion. Balanced digestions have been obtained at space loads in the range of 1.6 to $5.4 \mathrm{~kg} \mathrm{VS} \mathrm{m}^{-3}$ day $^{-1}$ and detention times of 10 days at the minimum. A retarded digestion occurred at a loading rate of $8.1 \mathrm{~kg} \mathrm{VS} \mathrm{m}^{-3} \mathrm{day}^{-1}$ and a 10-day detention time.

2. An almost optimum digestion for obtaining a satisfactory reduction of odorous components is achieved at a $75 \mathrm{~g}$ TS/litre concentration of the piggery waste at a 15-day detention time.

3. When the space load is increased, the methane production is more strongly affected by the detention time than by the TS concentration of the manure feed.

4. The propionic acid concentration is a useful indicator of process stability.

5. At decreasing detention times the methane production per $\mathrm{kg}$ VS added de- 
creases, mainly because hydrolysis - which is the primary rate-limiting step - becomes incomplete. At a high organic load, viz $8.1 \mathrm{~kg} \mathrm{VS} \mathrm{m}^{-3} \mathrm{day}^{-1}$, the methane formation becomes the rate-limiting factor.

6. It appears that the anaerobic digestion of piggery waste is hardly affected by high ammonia nitrogen concentrations (as high as $4000 \mathrm{mg} \mathrm{NH}_{4}-\mathrm{N} /$ litre) in combination with a $\mathrm{pH}$ of 7.9 .

7. Indole and skatole are the odorous components with the slowest elimination rate. The reduction of these components decreases (1) at decreasing detention times and (2) at increasing TS concentrations of the manure feed.

\section{Acknowledgments}

The author wishes to thank G. Lettinga (Dept. of Water Purification, Agricultural University, Wageningen, the Netherlands) for his close co-operation and S. Spoelstra (Dept. of Microbiology, Agricultural University, Wageningen, the Netherlands) for the use of his method of analysing aromatic components. Part of the work was conducted at the Central Institute for Nutrition and Food Research (CIVO-TNO), Zeist, the Netherlands. J. de Waart provided the use of the facilities there and his co-operation is acknowledged.

\section{References}

Fohr, P. G., 1974. Analyse van water, afvalwater en afvalwaterslib. $\mathrm{H}_{2} \mathrm{O} 7$ (19) 397.

Gramms, L. C., L. B. Polkowski \& S. A. Witzel, 1971. Anaerobic digestion of farm animal wastes. Trans. Am. Soc. agric. Engrs 14 (1) 7-13.

Hart, S. A., 1963. Digestion tests of livestock wastes. J. Water Poll. Control Fedn 35 (6) 748-757.

Hobson, P. N., S. Bousfield \& R. Summers, 1974. Anaerobic digestion of organic matter. CRC crit. Rev. environm. Control (June) 131-191.

Hobson, P. N. \& B. G. Shaw, 1973. The anaerobic digestion of waste from an intensive pig unit. Water Res. 7: 437-449.

Kroeker E. J., H. M. Lapp, D. D. Schulte \& A. B. Sparling, 1975. Cold weather energy recovery from anaerobic digestion of swine manure. In: William J. Jewell (Ed.), Energy, agriculture and waste management. Proc. Cornell Univ. agric. Waste Management Conf. (1975) 337-352.

Lawrence, A. W. M., 1971. Anaerobical biological waste treatment systems. In: Agricultural waste: Principles and guidelines for practical solutions. Proc. Cornell Univ. Conf. agric. Waste Management (1971) 79-92.

Loehr, R. C., 1969. Animal wastes - A national problem. J. sanit. Engng Div. Am. Soc, agric. Engrs 95, No SA2: 189-221.

McCarthy, P. L., 1964. Aanaerobic waste treatment fundamentals, Part I, II, III and IV. Public Works 95, No 9, 10, 11 and 12.

Maki, L. W., 1954. Experiments on the microbiology of cellulose decomposition in a municipal sewage plant. Anthonie van Leeuwenhoek 20: 185.

Melbinger, N. R. \& J. Donnellon, 1971. Toxic effects of ammonia nitrogen in high-rate digestion. J. Water Poll. Control Fedn 43 (8) 1658-1668.

Miner, J. R. \& J. R. Smith (Ed.), 1975. Livestock waste management with pollution control. North Central Regional Research Publication 222. Midwest Plan Service Handbook MWPS19 ; pp. 83.

Patel, J. B. \& R. B. Patel, 1971. Biological treatment of poultry manure reduces pollution. Compost Sc. 18 (5) 18-20. 
Schaefer, J., J. M. H. Bemelmans \& M. C. ten Noever de Brauw, 1974. Onderzoek naar de voor de stank van varkensmesterijen verantwoordelijke componenten. Landbouwk. Tijdschr. 86: $228-232$.

Schmid, L. A. \& R. I. Ripper, 1969. Characterization and anaerobic digestion. In: Animal waste management. Proc. Cornell Univ. Conf. agricultural Waste Management (1969).

Spoelstra, S., 1977. Simple phenols and indoles in anaerobically stored piggery waste. J. Sci. Fd Agric. (in press). 